\title{
PERANCANGAN FRAMEWORK DECISION SUPPORT SYSTEM UNTUK PERSEDIAAN BAHAN BAKU DALAM PENGENDALIAN PROSES PRODUKSI DENGAN ODOO MANUFACTURING DI PT. 3A PRECISE SCALE
}

\section{Yudi Maulana}

\author{
Dosen Program Teknik Inndustri Universitas Pamulang \\ dosen01302@unpam.ac.id
}

\begin{abstract}
ABSTRAK
PT. 3A Precise Scale merupakan salah satu perusahaan yang bergerak dalam bidang manufaktur terutama dalam pembuatan timbangan digital yang tidak terlepas dari masalah proses produksi yang terhambat karena tidak terkontrolnya persediaan bahan baku. Material Requirement Planning (MRP) merupakan metode penjadwalan yang digunakan untuk purchased planned order dan manufactured planned orders, yang kemudian akan dianalisis berkelanjutan berkenaan dengan persediaan kapasitas dan keseimbangan dalam perencanaan kebutuhan kapasitas. Kesimpulan yang dapat diambil pada MRP ini mempermudah dalam kelancaran proses produksi seperti safety stock untuk timbangan digital Alexa yaitu 289 unit, DLE 329 unit dan untuk Precio yaitu 489 unit, sedangkan untuk hasil reorder point atau titik pemesanan kembali untuk timbangan digital Alexa yaitu 1617 unit, DLE 1843 unit dan untuk Precio yaitu 2735 unit, kemudian untuk mengendalikan secara sistemastis perusahaan harus menggunakan sistem Odoo Manufacturing.
\end{abstract}

Kata Kunci: Perencanaan Kebutuhan Material, Odoo Manufacturing

\section{PENDAHULUAN}

Mesin merupakan salah satu aspek terpenting dalam bidang industri manufaktur maupun industri jasa karena mesin merupakan investasi yang memiliki nilai besar pada sebuah perusahaan manufaktur. Dalam kegiatan produksi, sangat diharapkan proses berlangsung secara lancar dan tanpa adanya hambatan yang berarti, oleh karenanya mesin harus berada pada kondisi dimana tingkat ketersediaan dan keandaalanya tinggi. Jika terdapat gangguan pada salah satu mesin maka kegiatan produksipun harus terhenti, sehingga produk yang dihasilkan tidak optimal dan menimbulkan kerugian bagi perusahaan, Kerusakan pada mesin dapat terjadi diantaranya ialah human error, terjadi kedaan darurat, kurangnya perawatan dan sebagainya. Untuk mengevaluasi kondisi mesin tersebut diperlukan suatu anlisis yang memungkinkan untuk meningkatkan produktifitas pada setiap mesin. Salah satu analisis yang biasa digunakan untuk menjaga tingkat keandalan mesin ialah Rantai Markov, Rantai Markov digunakan untuk menentukan peluang jangka panjang dari kondisi mesin tersebut.. Tingkat keandalan mesin yang rendah mengakibatkan kerugian bagi perusahaan dan kemungkinan membahayakan pekerja, sehingga diperlukan suatu pengukuran dan analisis tingkat keandalan atau reliabilitas suatu mesin untuk membantu perusahaan agar melakukan tindakan perawatan yang teratur.

Mesin yang digunakan pada perusahaan rata-rata berumur lima sampai enam tahun sesuai dengan karakteristik atau type mesin yang ada. Mesin atau peralatan produksi PT. Cardsindo mengalami kerusakan atau gangguan yang menyebabkan proses produksi terhenti, kenyataan yang ada di lapangan mesin atau peralatan baru akan dilakukan pemeliharan ketiak terjadi kerusakan, hal ini dapat mengakibatkan biaya kerusakan yang cukup tinggi dikarenakan kurang atau tidak adanya perencanaa pemeliharaan secara yang sitemati yang dilakukan. Berdasarkan masalah yang terjadi dialapangan peneliti mengusulkan agar dilakukan perencanaan pemrawatan mesin yanga da denagn Teknik atau metode markov chain yang diharapkan dengan metode tersebut dapat menurunkan biaya pemelihraan yang ada saat ini dengan sistematis.

Faktor penyebab minimnya produktifitas suatu mesin ataupun peralatan dapat menimbulkan kerugan yang nyata bagi setiap perusahaan hal ini sisebabkan oleh kuranya efektifitas dan effisiensi pada suatu mesin ataupun peralatan ayang ada. Ada enam faktor 
penyebab yang biasa disebut 6 kerugian besar (six big loses), 6 kerugian besar yang dimaksud ialah downtime seperti breakdown (kerusakan mesin / peralataan), speed losses yang terdiri atas idling and minor stoppage losses sering disebabkan oleh kejadian-kejadian seperti pemberhentian mesin sejenak, dan setup and adjustment (kesalahan pemasangan dan penyetelan). Kemacetan mesin dan reduce speed losses adalah kerugian yang disebabkan karena mesin tidak berkerja secara optimal (penurunan kecepatan operasi) terjadi jika kecepatan aktual operasi pada mesin/peralatam jauh lebih kecil dari pada kecepatan optimal atau kecepatan mesin yang dirancang. Defect losess, terdiri atas Process defect yaitu merupakan kerugian yang di sebabkan karena adanya produk yang cacat maupun karena kerja produk pada proses ulang dan reduced yield losess di sebabkan oleh material yang tidak digunakan atau dengan kata lain sampah bahan baku.

Dalam memproduksi produknya perusahaan ini memiliki banyak mesin yang memiliki spesifikasi dan karakter yang berbeda. Intensitas pemakaian mesin yang lama menyebabkan performa mesin mengalami penurunan dan terkadang mesin mengalami masalah sehingga menghambat jalannya proses produksi. Belum optimalnya proses perawatan membuat tingginya nilai downtime dan proses perbaikan memakan waktu. Dari permasalahan tersebut maka dibuat usulan untuk melakukan penelitian guna menganalisa apakah pelaksanaan perawatan tersebut sudah maksimal, penelitian tersebut dapat diterapkan dengan menganalisa manajemen perawatan dengan penerapan metode Markov Chain.

\section{DASAR TEORI}

Fungsi produksi yaitu merupakan bagian pada suatu organisasi, yang sangat berkaitan dengan transformasi dari berbagai input ke dalam suatu output yang dibutuhkan (produk) dan memiliki tingkat kualitas yang dibutuhkan. Produksi disebut juga sebagai konversi setahap demi setahap dari satu bentuk materi menjadi suatau bentuk lain melalui proses kimia ataupun mekanik agar membuat atau meningkatkan utilitas produk bagi penggunanya. Jadi bisa dikatakan produksi adalah merupakan proses penambahan nilai. Dalam setiap tahap pemrosesan, maka akan ada penambahan suatu nilai. Edwood Buffa menjelaskan bahwa produksi sebagai suatu proses dimana suatu barang dan jasa tersebut dibuat. Ada beberapa contoh dalam produksi yaitu: pembuatan produk yang akan dibuat seperti, boiler dengan kapasitas yang spesifik, membangun flat, dan beberapa pekerjaan struktural untuk pelanggan tertentu, dll., bisa juga pembuatan sebuah produk standar seperti, mobil, kereta, bus, sepeda motor, radio, hand phone, dan televise. Produksi ditandai oleh pembuatan satu atau beberapa jumlah produk yang dirancang dan diproduksi sesuai dengan spesifikasi pelanggan dalam waktu dan biaya tertentu. Fitur itu yang membedakan antara volume rendah dan variasi produk yang tinggi. Contohnya sebuah job shop terdiri dari beberapa mesin serba guna yang dapat diatur dalam berbagai departemen. Pada setiap pekerjaan yang menuntut persyaratan teknologi yang unik, menuntut pemrosesan pada mesin dalam jumlah urutan tertentu. Tren penawaran dan permintaan membentuk dasar ekonomi modern. Setiap barang atau jasa spesifik akan memiliki pola penawaran dan permintaan sendiri berdasarkan harga, utilitas, dan preferensi pribadi. Jika orang menuntut barang dan mau membayar lebih untuk itu, produsen akan menambah pasokan. Ketika pasokan meningkat, harga akan turun dengan tingkat permintaan yang sama. Idealnya, pasar akan mencapai titik keseimbangan di mana penawaran sama dengan permintaan (tidak ada kelebihan pasokan dan tidak ada kekurangan) untuk titik harga tertentu; pada titik ini, utilitas konsumen dan keuntungan produsen dimaksimalkan. Dasar-dasar Pasokan

Konsep penawaran dalam ekonomi adalah kompleks dengan banyak rumus matematika, aplikasi praktis dan faktor-faktor yang berkontribusi. Sementara penawaran dapat merujuk pada apa pun yang laris terjual di pasar yang kompetitif, penawaran paling sering digunakan untuk merujuk pada barang, jasa, atau tenaga kerja. Salah satu faktor terpenting yang mempengaruhi pasokan adalah harga barang. Secara umum, jika harga barang meningkat maka pasokan akan meningkat. Harga barang terkait dan harga input (energi, bahan baku, tenaga kerja) juga memengaruhi pasokan karena berkontribusi pada peningkatan harga keseluruhan barang yang dijual.

Pasokan diwakili dalam ekonomi mikro oleh sejumlah rumus matematika. Fungsi dan persamaan penawaran menyatakan hubungan antara penawaran dan faktor-faktor yang mempengaruhi, seperti yang disebutkan di atas atau bahkan tingkat inflasi dan pengaruh pasar 
lainnya. Pada kurva penawaran selalu menggambarkan anatara hubungan harga barang dan jumlah yang ditawarkan. Kekayaan informasi dapat diperoleh dari kurva penawaran, seperti pergerakan (disebabkan oleh perubahan harga), pergeseran (disebabkan oleh perubahan yang tidak terkait dengan harga barang) dan elastisitas harga.

\section{Sejarah Pasokan}

Pasokan dalam ekonomi dan keuangan seringkali, jika tidak selalu, dikaitkan dengan permintaan. Hukum penawaran dan permintaan adalah prinsip dasar dan fundamental ekonomi. Hukum penawaran dan permintaan adalah teori yang menggambarkan bagaimana persediaan suatu barang dan permintaan untuk itu berinteraksi. Secara umum, jika pasokan tinggi dan permintaan rendah, harga yang sesuai juga akan rendah. Jika pasokan rendah dan permintaan tinggi, harganya juga akan tinggi. Teori ini mengasumsikan persaingan pasar dalam sistem kapitalis. Penawaran dan permintaan dalam ekonomi modern secara historis dikaitkan dengan John Locke dalam iterasi awal, serta secara definitif digunakan oleh Adam Smith yang terkenal, "Penyelidikan tentang Sifat dan Penyebab Kekayaan Bangsa-Bangsa," diterbitkan pada 1776.

Representasi grafis dari data kurva penawaran pertama kali digunakan pada tahun 1870-an oleh teks-teks ekonomi Inggris, dan kemudian dipopulerkan dalam buku teks seminal "Prinsip Ekonomi" oleh Alfred Marshall pada tahun 1890. Sudah lama diperdebatkan mengapa Inggris adalah negara pertama yang merangkul, memanfaatkan dan mempublikasikan teori penawaran dan permintaan, dan ekonomi secara umum. Munculnya revolusi industri dan kekuatan ekonomi Inggris berikutnya, yang meliputi produksi besar-besaran, inovasi teknologi, dan sejumlah besar tenaga kerja, telah menjadi penyebab yang dibahas dengan baik.

Sejarah 'Pasokan'

Pasokan dalam ekonomi dan keuangan seringkali, jika tidak selalu, dikaitkan dengan permintaan. Hukum penawaran dan permintaan adalah prinsip dasar dan fundamental ekonomi. Hukum penawaran dan permintaan adalah teori yang menggambarkan bagaimana persediaan suatu barang dan permintaan untuk itu berinteraksi. Secara umum, jika pasokan tinggi dan permintaan rendah, harga yang sesuai juga akan rendah. Jika pasokan rendah dan permintaan tinggi, harganya juga akan tinggi. Teori ini mengasumsikan persaingan pasar dalam sistem kapitalis. Penawaran dan permintaan dalam ekonomi modern secara historis dikaitkan dengan John Locke dalam iterasi awal, serta secara definitif digunakan oleh Adam Smith yang terkenal, "Penyelidikan tentang Sifat dan Penyebab Kekayaan Bangsa-Bangsa," diterbitkan pada 1776.

Representasi grafis dari data kurva penawaran pertama kali digunakan pada tahun 1870 -an oleh teks-teks ekonomi Inggris, dan kemudian dipopulerkan dalam buku teks seminal "Prinsip Ekonomi" oleh Alfred Marshall pada tahun 1890. Sudah lama diperdebatkan mengapa Inggris adalah negara pertama yang merangkul, memanfaatkan dan mempublikasikan teori penawaran dan permintaan, dan ekonomi secara umum. Munculnya revolusi industri dan kekuatan ekonomi Inggris berikutnya, yang meliputi produksi besar-besaran, inovasi teknologi, dan sejumlah besar tenaga kerja, telah menjadi Syarat \& Konsep Terkait yang dibahas dengan baik

Istilah dan konsep terkait untuk memasok dalam konteks hari ini termasuk keuangan rantai pasokan dan pasokan uang. Jumlah uang beredar merujuk secara khusus pada seluruh persediaan mata uang dan aset likuid di suatu negara. Ekonom akan menganalisis dan memantau pasokan ini, merumuskan kebijakan dan peraturan berdasarkan fluktuasi melalui pengendalian suku bunga dan langkah-langkah lain semacam itu. Data resmi tentang suplai uang suatu negara harus dicatat secara akurat dan dipublikasikan secara berkala. Krisis utang negara Eropa, yang dimulai pada 2009, merupakan contoh yang baik tentang peran pasokan uang suatu negara dan dampak ekonomi global.

Keuangan rantai pasokan global adalah konsep penting lain yang terkait dengan pasokan di dunia global saat ini. Pembiayaan rantai pasokan bertujuan untuk secara efektif menghubungkan semua prinsip transaksi, termasuk pembeli, penjual, lembaga pembiayaan — dan dengan proxy pemasok - untuk menurunkan biaya keuangan keseluruhan dan mempercepat proses bisnis. Pendanaan rantai pasokan seringkali dimungkinkan melalui platform berbasis teknologi, dan memengaruhi industri seperti sektor otomotif dan ritel. 
Kondisi produksi barang yang dipasok juga signifikan; misalnya, ketika kemajuan teknologi meningkatkan kualitas barang yang dipasok, atau jika ada inovasi yang mengganggu, seperti ketika kemajuan teknologi membuat barang usang atau kurang laris. Peraturan pemerintah juga dapat memengaruhi pasokan, seperti hukum lingkungan, serta jumlah pemasok (yang meningkatkan persaingan) dan ekspektasi pasar. Contohnya adalah ketika hukum lingkungan tentang ekstraksi minyak mempengaruhi pasokan minyak tersebut.

Menurut Rangkuti (2011:1) didalam bukunya menyatakan bahwa persediaan merupakan suatu yang meliputi beberapa barang milik perusahaan dengan maksud untuk dpaat dijual dalam suatu kurun waktu tertentu, atau persediaan barang-barang yang dalam prose pengerjaan atau proses produksi, ataupun persediaan bahan baku yang sedang menunggu penggunaannya dalam suatu proses produksi.

\section{Jenis Persediaan}

Ada beberapa jenis persediaan, setiap jenis persediaan mempunyai karakteristik khusus tersendiri dan cara pengelolaannya yang berbeda. Jenis-jenis persediaan jika ditinjau dari segi fisiknya terbagi menjadi beberapa jenis yaitu:

1. Persediaan Bahan Mentah

Persediaan bahan mentah adalah persediaan bahan yang masih belum memuat elemen-elemen biaya didalam bahan tersebut. misal pada pabrik furniture maka bahan mentahnya masih kayu gelondongan, belum ada penanganan lebih lanjut yang dapat diposting menjadi biaya perusahaan.

2. Persediaan Komponen-Komponen Rakitan Persediaan komponen-komponen rakitan ini sangat mudah dijumpai di industri elektronik dan otomotif. Setiap pabrik elektronik pasti memiliki pabrik perakitannya sendiri. Dalam sebuah pabrik perakitan tersebut ada bermacam-macam persediaan komponen-komponen rakitan. Seperti dalam sebuah pabrik timbangan digital maka Printed Circuit Board (PCB) merupakan persediaan komponen-komponen rakitan yang siap dirakit menjadi laptop.

3. Persediaan Bahan Pembantu atau Persediaan Bahan Penolong

Persediaan bahan penolong ini merupakan katalisator dari produksi bahan tersebut. jadi bahan tersebut bukan merupakan bagian atau komponen barang jadi namun bahan tersebut sangat diperlukan dalam produksi.

\section{Persediaan Dalam Proses}

Persediaan dalam proses atau biasa disebut persediaan setengah jadi merupakan persediaan yang merupakan keluaran dari tiap-tiap proses, namun masih belum sempurna dan masih harus dilakukan pengolahan lagi.

5. Persediaan Barang Jadi

Persediaan barang jadi merupakan suatu barang yang sudah tidak perlu pengolahan lagi. Jadi tinggal di pasarkan dan siap untuk dijual, dengan kata lain semua bahan dan unsur biaya produksi sudah melekat pada barang yang dimaksud. Manajemen persediaan telah diakui sebagai salah satu aspek terpenting dari suatu organisasi. Manajemen inventaris menjawab pertanyaan tentang bagaimana cara menyeimbangkan antara persediaan tinggi dan rendah untuk memaksimalkan manfaat dengan risiko minimal. Dengan inventaris yang tinggi, perusahaan akan menderita biaya penyimpanan yang tinggi dan using stok yang berlebihan dan di sisi lain dengan persediaan rendah akan ada yang buruk

tingkat layanan dan biaya kekurangan tinggi. Mengelola persediaan memiliki dampak langsung

atas laba perusahaan. (Nenes, Panagiotioudou \& Tagaras 2009, 313.).

Level minimum dan maksimum harus sesuai dengan permintaan atau akan ada

kekurangan persediaan atau ada kelebihan persediaan yang membutuhkan ruang rak.

(Gardner 2004, 100) Untuk pemasok yang tidak dapat diandalkan, pelanggan mungkin menetapkan ketat

level minimum dan maksimum. Semakin ketat levelnya semakin sedikit fleksibilitasnya

pemasok telah memutuskan jadwal pengisian optimal. (Claassen et al. 2008, 407). Dalam studi kualitatif yang dilakukan oleh Claassen et al. mereka menemukan itu di mempraktikkan nilai minimum dan maksimum ini sangat ketat dibandingkan dengan teori yang ada enabler fleksibilitas. (Claassen et al. 2008, 408.). Setelah menyetujui nilai minimum dan maksimum (S), hukumannya adalah ditentukan per potong yang berada di bawah s atau di atas S. Nilai S-s harus besar cukup untuk memberikan fleksibilitas yang cukup kepada pemasok. (Boone, 2001, 332). Dalam kasus ini belajar oleh Zammori et al. 2009 mereka menggunakan nilai minimum yang mencakup konsumsi untuk waktu lebih dari dua kali waktu pengiriman. Nilai maksimum mereka didefinisikan dengan mempertimbangkan variabel interval pengiriman (seminggu sekali) dan sebagainya pemasok dapat mengirimkan 
muatan truk penuh (perbedaan antara $\mathrm{S}$ dan $\mathrm{s}$ sama dengan) muatan truk penuh dan $25 \%$ ekstra untuk memberikan kelonggaran). Mereka memiliki waktu pengiriman satu hari dengan pemasok lokal dan nilai minimumnya lebih dari dua kali jumlah yang dikonsumsi selama waktu pengiriman. Mereka mendefinisikan margin dengan menggunakan jumlah muatan truk penuh sebagai basis dan kemudian menambahkan 5 buah yang dalam studi kasus mereka berhubungan dengan seperempat truk dan sekitar 1 hari pemakaian. (Zammori et al. 2009, 175)

Apa itu Perencanaan Kebutuhan Material (MRP)?

Material Requirements Planning (MRP) adalah sistem manajemen inventaris berbasis komputer yang dirancang untuk meningkatkan produktivitas bisnis. Perusahaan menggunakan sistem perencanaan persyaratan bahan untuk memperkirakan jumlah bahan baku dan menjadwalkan pengirimannya.

Bagaimana cara kerja MRP

MRP dikembangkan untuk menjawab tiga pertanyaan: Apa yang dibutuhkan? Berapa yang dibutuhkan? Kapan itu perlu? "MRP bekerja mundur dari rencana produksi produk jadi, yang diubah menjadi daftar persyaratan untuk subset, komponen bagian dan bahan baku yang diperlukan untuk menghasilkan produk akhir dalam jadwal yang ditetapkan.

Dengan menganalisis data mentah - seperti bill of lading dan umur simpan bahan yang disimpan - teknologi ini memberikan informasi yang bermakna kepada para manajer tentang tenaga kerja dan kebutuhan pasokan mereka, yang dapat membantu perusahaan meningkatkan efisiensi produksi mereka.

Sistem MRP: Sejarah

Perencanaan kebutuhan material adalah yang pertama dari sistem teknologi informasi terintegrasi (TI) yang bertujuan untuk meningkatkan produktivitas perusahaan yang menggunakan teknologi komputer dan perangkat lunak. Sistem manajemen persediaan MRP pertama berkembang pada tahun 1940-an dan 1950-an. Mereka menggunakan komputer mainframe untuk mengekstrapolasi informasi dari bill of material ke produk jadi tertentu dalam rencana produksi dan pembelian. Segera, sistem MRP diperluas untuk memasukkan loop umpan balik informasi, sehingga manajer produksi dapat mengubah dan memperbarui entri sistem yang diperlukan.
MRP generasi berikutnya, perencanaan sumber daya manufaktur (MRP II), juga memasukkan aspek pemasaran, keuangan, akuntansi, teknik, dan sumber daya manusia ke dalam proses perencanaan. Konsep terkait yang berkembang dalam MRP adalah ERP (Enterprise Resource Planning), yang menggunakan teknologi komputer untuk menghubungkan berbagai area fungsional dari seluruh perusahaan komersial. Ketika analisis dan teknologi data menjadi lebih canggih, sistem yang lebih komprehensif dikembangkan untuk mengintegrasikan MRP dengan aspek lain dari proses pembuatan.item akhir tertentu dan komponennya, dan kemudian mengumpulkan jumlah jam yang diperlukan pada masing-masing

MRP II

Perencanaan Sumberdaya Pabrikan (MRP II) menanamkan prosedur tambahan untuk mengatasi kekurangan MRP. Selain itu, MRP II berupaya untuk menjadi sistem manufaktur terintegrasi dengan membawa

bersama bidang fungsional lainnya seperti pemasaran dan keuangan. Fungsi tambahan MRP II termasuk peramalan, manajemen permintaan, perencanaan kapasitas kasar (RCCP), dan perencanaan kebutuhan kapasitas (CRP), penjadwalan aturan pengiriman, dan kontrol input / output. MRP II berfungsi

dalam hierarki yang membagi perencanaan menjadi perencanaan jangka panjang, perencanaan jangka menengah, dan kontrol jangka pendek.

\section{Output MRP}

Output MRP secara umum menurut Nasution (2012:254) adalah:

1. Dapat memberikan catatan tentang sebuah pesanan penjadwalan yang mesti dilakukan dan direncanakan secara baik dari pabrik internal maupun supplier.

2. Dapat memberikan indikasi terhadap penjadwalan ulang.

3. Dapat memberikan indikasi terhadap pembatalan atas suatu pesanan.

4. Dapat memberikan indikasi terhadap keadaan persediaan.

\section{Definisi}

perencanaan kebutuhan material (MRP)

Perencanaan kebutuhan material (MRP) adalah sistem untuk menghitung bahan dan komponen yang dibutuhkan untuk memproduksi suatu produk. Ini terdiri dari tiga langkah utama: melakukan inventarisasi bahan dan komponen, 
mengidentifikasi yang mana yang diperlukan dan kemudian menjadwalkan produksi atau pembelian mereka.

Tujuan Material Requirements Planning (MRP)

Tujuan dari penerapan Material

Requirements Planning (MRP) menurut

Purnomo (2010:108) adalah sebagai

berikut:

\section{Meminimalisasi Persediaan}

1. Dengan menggunakan metode MRP pengadaan atas komponen-komponen yang diperlukan untuk rencana produksi dapat dilakukan sebatas yang diperlukan saja sehingga biaya persediaan dapat diminimalkan.

2. Mengurangi Resiko Keterlambatan Produksi atau Pengiriman.

3. MRP mengidentifikasikan komponenkomponen yang diperlukan baik dari segi jumlah maupun waktu dengan memperhatikan lead time (tenggang waktu) produksi maupun pengadaan atau pembelian komponen, maka resiko kehabisan bahan yang akan diproses dapat diminimalkan.

4. Menentukan Pelaksanaan Rencana Pemesananng Diperlukan.

5. MRP akan memberikan indikasi waktu pemesanan atau pembatalan pemesanan.

Menentukan penjadwalan ulang atau pembatalan atas suatu jadwal yang sudah direncanakan.

Adapun langkah-langkah proses perhitungan MRP menurut Purnomo (2010:113) antara lain:

Proses Netting

1. Yaitu menentukan kebutuhan bersih (Net Requirement). Besarnya kebutuhan bersih adalah selisih antara kebutuhan kotor (Gross Requirement) dengan persediaan yang ada ditangan (on hand).

2. Proses Loting

3. Yaitu menentukan jumlah pesanan tiap komponen yang didasarkan kebutuhan bersih (Net Requirement) yang dihasilkan dari proses netting.

4. Proses Offseting

Yaitu menentukan waktu pemrosesan atau waktu pemesanan tiap komponen dengan menggunakan tenggang waktu (lead time) dari jadwal produksi atau jadwal penggunaan tiap komponen.

\section{Proses Explosion}

Yaitu Menghitung jumlah tiap komponen berdasarkan jumlah produk akhir yang akan diproduksi dengan menentukan BOM (Bill of material file) dan kebutuhan kotor tiap komponen.

\section{METODE DAN TEKNIK PENGUKURAN}

\section{Lokasi Perusahaan}

Untuk memfokuskan kegiatan penelitian yang dilakukan, maka lokasi penelitian dibatasi berdasarkan tempat dan objek penelitian sebagai berikut:

1. Tempat dan Waktu Penelitian

Penelitian ini dilakukan di PT. 3A Precise Scale yang berlokasi di jalan Veteran, kampung Kebon Kelapa, RT.05/RW.04, desa Pasar kemis, kecamatan Pasar Kemis, kabupaten Tangerang Banten, kode pos 15560 dan waktu penelitian dilakukan dari bulan April 2018 sampai dengan bulan September 2018.

2. Objek Penelitian

Pelaksannaan penelitian ini dilakukan pada bagian gudang dan bagian produksi, pada proses pembuatan timbangan digital Precio.

\section{Jenis Penelitan}

Penelitian ini merupakan jenis penelitian deskriptif kuantitatif. Jenis penelitian deskriptif kuantitatif ini adalah jenis yang menggambarkan data masalah yang ada dan berkembang pada saat penelitian dilakukan (data aktual yang kemudian dianalisis untuk menguji hipotesis yang telah dilakukan) melihat keadaan serta mengumpulkan beberapa data berdasarkan fakta-fakta yang ada pada perusahaan..

sekunder meliputi data perusahaan berupa

\section{Teknik Pengumpulan Data}

Teknik pengumpulan data yang digunakan dalam penelitian ini adalah dengan melakukan pengamatan langsung di perusahaan yang menjadi objek penelitian. Teknik pengumpulan data yang digunakan dalam penelitian ini adalah:

1. Wawancara

Merupakan suatu cara untuk mendapatkan data atau informasi dengan tanya jawab secara langsung pada orang yang mengetahui tentang objek yang diteliti. Dalam hal ini adalah dengan pihak manajemen atau karyawan PT. 3A Precise Scale yaitu data mengenai jenis-jenis produk yang bermasalah dan mencari tau penyebabnya dalam proses produksi serta bahan baku yang digunakan.

2. Observasi 
Teknik ini penulis melakukan pengamatan atau peninjauan secara langsung di tempat penelitian yaitu di PT. 3A Precise Scale dengan mengamati sistem atau cara kerja pegawai yang ada, mengamati proses produksi dari awal sampai akhir, dan pengendalian persediaan bahan baku.

3. Dokumentasi

Yaitu dengan mempelajari dokumen-dokumen perusahaan yang berupa laporan kegiatan produksi, laporan jumlah produksi dan jumlah persediaan bahan baku, rencana kerja, serta dokumen kepegawaian.

\section{Definisi Operasional Variabel}

Setelah semua data yang diperlukan sudah diperoleh, maka selanjutnya akan dilakukan analisis data, yaitu:

1. Menentukan Master Production Schedule (MPS)

2. Menentukan inventory status reqord (catatan persediaan) dan bill of material (daftar persediaan)

3. Menentukan Material Requirement Planning (MRP)

4. Menentukan Safety Stock (persediaan pengaman)

5. Menentukan Reorder Point (titik pemesanan kembali)

Flowchart Penelitian

Flowchart merupakan gambaran atau bagan yang memperlihatkan urutan dan hubungan antar proses peserta pernyataannya. Dengan menggunakan flowchart akan memudahkan kita untuk melakukan pengecekan bagian-bagian yang terlupakan dalam analisa masalah. Flowchart dari kegiatan pengolahan dan penetapan metode yang akan digunakan pada saat penyusunan penelitian mengenai permasalahan persediaan bahan baku timbangan digital Precio yang dilakukan di PT. 3A Precise Scale dapat dilihat pada Gambar 3

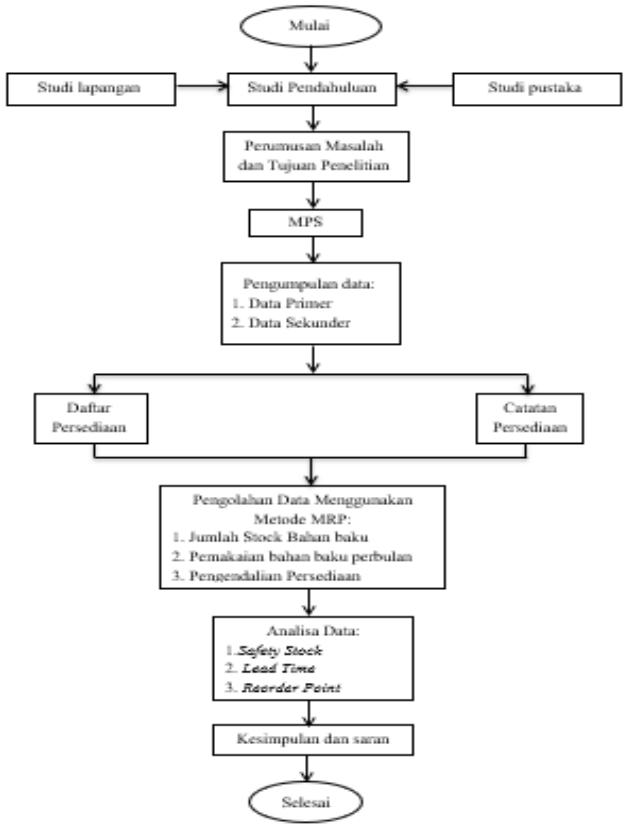

IV. HASIL DAN PEMBAHASAN

Untuk menyelesaikan penelitian ini, dimana data awal merupakan kunci agar masalah ini terselesaikan, data tesebut ada pada Tabel 4.1 dibawah ini:

Tabel 4.1 Penjualan Timbangan Digital Tahun 2018

ENJUALAN TIMBANGAN DIGITAL TAHUN 2018DI PT. 3A PRECIS

\begin{tabular}{|c|c|c|c|c|c|}
\hline \multirow{2}{*}{ NO } & \multirow{2}{*}{ BULAN } & \multicolumn{3}{|c|}{ NAMA PRODUK } & \multirow{2}{*}{ TOTAL } \\
\hline & & ALEXA & DLE & PRECIO & \\
\hline 1 & JANUARI & 750 & 600 & 1050 & 2400 \\
\hline 2 & FEBRUARI & 680 & 500 & 1300 & 2480 \\
\hline 3 & MARET & 800 & 700 & 1000 & 2500 \\
\hline 4 & APRIL & 700 & 900 & 850 & 2450 \\
\hline 5 & MEl & 840 & 750 & 970 & 2560 \\
\hline 6 & JUNI & 660 & 680 & 1300 & 2640 \\
\hline 7 & JULI & 200 & 1000 & 1400 & 2600 \\
\hline 8 & AGUSTUS & 560 & 920 & 1100 & 2580 \\
\hline 9 & SEPTEMB & 850 & 740 & 950 & 2540 \\
\hline 10 & OKTOBER & 780 & 630 & 1200 & 2610 \\
\hline 11 & NOVEMB & 640 & 780 & 1100 & 2520 \\
\hline 12 & DESEMBE & 510 & 880 & 1250 & 2640 \\
\hline \multicolumn{2}{|c|}{ TOTAL } & 7970 & 9080 & 13470 & 30520 \\
\hline
\end{tabular}

(Sumber: Dokumen PT. 3A Precise Scale)

Dalam data penjualan di atas, dimana total penjualan untuk semua produk timbangan digital di tahun 2018 sebesar 30520 unit dengan penjualan terendah pada bulan Januari 2018 yaitu sebesar 2400 unit 
dan penjualan tertinggi ada pada bulan Juni 2018 yaitu sebesar 2640 unit. Jadi rata-rata penjualan per bulannya yaitu sebesar 2543 unit untuk keseluruhan produk, sedangkan untuk prouk Alexa yaitu 664 unit, DLE yaitu 757 unit dan Precio yaitu 1123 unit.

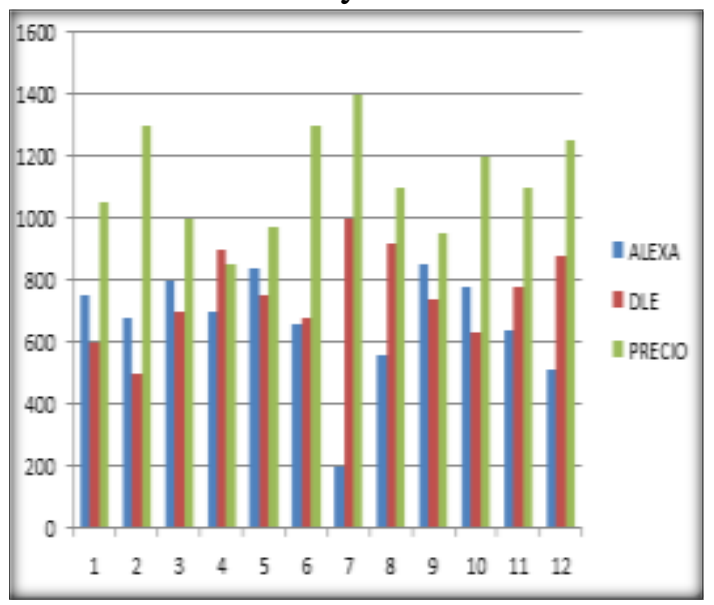

(Sumber: Dokumen PT. 3A Precise Scale)

Gambar 4.5 Diagram Hasil Penjualan Tahun 2018

\subsubsection{MPS}

Untuk mendapatkan data MPS terlebih dahulu kita harus mencari data penjualan tahun sebelumnya yaitu 2018 dengan nilai rata-rata penjualan 2534 unit setiap bulannya, adapun data MPS untuk tahun 2019 yaitu sebagai berikut:

Tabel 4.2 Jadwal Induk Produksi Tahun 2019

\begin{tabular}{|c|l|c|c|c|}
\hline \multirow{2}{*}{ NO } & \multirow{2}{*}{$\begin{array}{c}\text { BULA } \\
\text { N }\end{array}$} & \multicolumn{3}{|c|}{ JENIS PRODUK } \\
\cline { 3 - 5 } & & $\begin{array}{c}\text { ALEX } \\
\text { A }\end{array}$ & DLE & $\begin{array}{c}\text { PRECI } \\
\text { O }\end{array}$ \\
\hline 1 & JAN & 666 & 764 & 1128 \\
\hline 2 & FEB & 664 & 756 & 1122 \\
\hline 3 & MAR & 664 & 756 & 1122 \\
\hline 4 & APR & 664 & 756 & 1122 \\
\hline 5 & MEI & 664 & 756 & 1122 \\
\hline 6 & JUNI & 664 & 756 & 1122 \\
\hline 7 & JULI & 664 & 756 & 1122 \\
\hline 8 & AGU & 664 & 756 & 1122 \\
\hline 9 & SEPT & 664 & 756 & 1122 \\
\hline 10 & OKT & 664 & 756 & 1122 \\
\hline 11 & NOV & 664 & 756 & 1122 \\
\hline 12 & DES & 664 & 756 & 1122 \\
\hline
\end{tabular}

(Sumber: Pengolahan Data Sendiri)
Adapun data hasil produksi timbangan digital di PT. 3A Precise Scale untuk periode waktu dari bulan Januari 2018 sampai dengan bulan Desember 2018 dalam bentuk diagram balok di bawah ini adalah sebagai berikut:

Data di atas merupakan penjadwalan induk produksi untuk tahun 2019 yang didapatkan dari data penjualan ditahun sebelumnya dengan produk timbangan Alexa yaitu 664 unit, DLE 756 unit dan Precio 1122 unit.

Pembahasan ini menjelaskan tentang Material Requirement Planning (MRP) dari pembuatan timbangan digital. Hal ini akan menjelaskan tentang perencanaa dalam memesan bahan baku dan meminimumkan inventori bahan baku. Pembuatan mrp ini pun dibutuhkan beberapa data yang akan menjadi informasi dalam pengolahan MRP, yaitu struktur produk explotion, perencanaan agregat, schedule receipt, dan inventory status.

Data-data yang diperlukan dalam perhitungan MRP adalah rencana produksi agregat, struktur produk, bill of material, Scheduled Receipt dan Inventory Status. Struktur produk dan bill of naterial yang digunakan adalah model exploiton.

1. Timbangan Digital Alexa

Di bawah ini merupakan data-data dalam perhitungan MRP untuk timbangan digital Alexa:

Tabel 4.9 Perencanaan Produksi Agregat

\begin{tabular}{|c|c|c|}
\hline Periode & $\begin{array}{c}\text { Data } \\
\text { Peramalan }\end{array}$ & $\begin{array}{c}\text { Perencanaan } \\
\text { Agregat }\end{array}$ \\
\hline 1 & 750 & 666 \\
\hline 2 & 680 & 664 \\
\hline 3 & 800 & 664 \\
\hline 4 & 700 & 664 \\
\hline 5 & 840 & 664 \\
\hline 6 & 660 & 664 \\
\hline 7 & 200 & 664 \\
\hline 8 & 560 & 664 \\
\hline 9 & 850 & 664 \\
\hline 10 & 780 & 664 \\
\hline 11 & 640 & 664 \\
\hline 12 & 510 & 664 \\
\hline
\end{tabular}

(Sumber: Pengolahan Data Sendiri) 


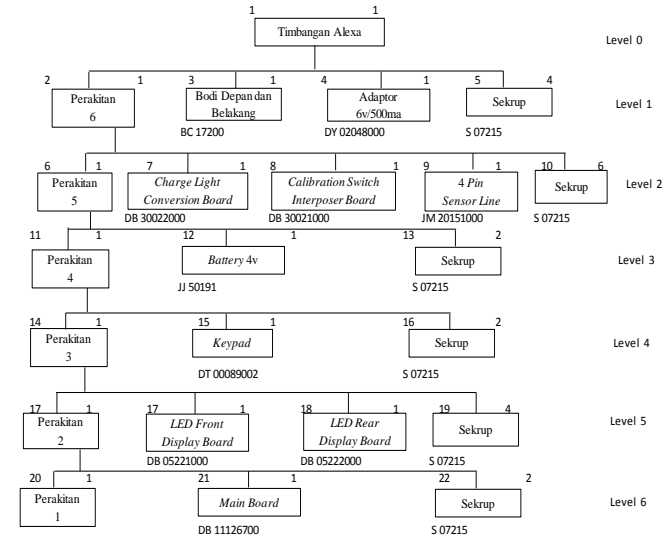

(Sumber: Pengolahan Data Sendiri)

Gambar 4.6 Struktur Produk Explotion Timbangan Alexa

Jadi, Safety Stock untuk timbangan digital Precio yaitu 5863 unit pertahun jika digunakan perbulan yaitu 489 unit.

\subsubsection{Reorder Point}

Dimana reorder point atau titik pemesanan kembali itu sangat penting bagi kelancara produksi agar tidak terhambat saat proses produksi yang nantinya mempengaruhi telatnya pengiriman kepada konsumen. Adapun untuk menentukan reorder point tersebut yaitu sebagai berikut:
1. Alexa
$\mathrm{ROP}=664 \times 2+289$
$\mathrm{ROP}=1617$

Jadi, reorder point untuk timbangan digital Alexa yaitu 1617. Dengan demikian, diharapkan datangnya material yang dipesan tidak akan melewati waktu sehingga akan melanggar safety stock. apabila pesanan dilakukan sesuadah melewati reorder point, maka matrial yang dipesan akan diterima setelah perusahaan terpaksa mengambil material dari safety stock.

$$
\begin{array}{ll}
\text { 2. DLE } & \mathrm{ROP}=757 \times 2+329 \\
\mathrm{ROP}=1843
\end{array}
$$

Jadi, reorder point untuk timbangan digital DLE yaitu 1843. Dengan demikian, diharapkan datangnya material yang dipesan tidak akan melewati waktu sehingga akan melanggar safety stock. apabila pesanan dilakukan sesuadah melewati reorder point, maka matrial yang dipesan akan diterima setelah perusahaan terpaksa mengambil material dari safety stock.
1. Precio

$$
\begin{aligned}
& \mathrm{ROP}=1123 \times 2+489 \\
& \mathrm{ROP}=2735
\end{aligned}
$$

Jadi, reorder point untuk timbangan digital precio yaitu 2735. Dengan demikian, diharapkan datangnya material yang dipesan tidak akan melewati waktu sehingga akan melanggar safety stock. apabila pesanan dilakukan sesuadah melewati reorder point, maka matrial yang dipesan akan diterima setelah perusahaan terpaksa mengambil material dari safety stock.

\section{KESIMPULAN}

Berdasarkan penelitian yang dilakukan, 5.1 Kesimpulan

Kesimpulan yang dapat diambil dari hasil penelitian proses penerapan sistem ERP, yaitu:

1. Konsep analisa perancangan framework decission support system untuk persediaan bahan baku menggunakan sistem Odoo Manufacturing yang memudahkan dan mampu menghasilkan sistem kerja yang efektif serta efisien bagi karyawan maupun bagi perusahaan dengan menggunakan software odoo, karena software odoo ini mampu mendetektsi persediaan bahan baku yang ada di dalam perusahaan secara online dan otomatis tanpa harus mencatatnya secara manual. Dalam software odoo ini setiap orang bisa mengaksesnya menggunakan gadget untuk melihat ketersediaan bahan baku yang ada di dalam perusahaan, jadi terpantau oleh setiap karyawan maupun pemimpin perusahaan.

2. Setelah mengaplikasikan konsep MRP dalam penerapan persediaan bahan baku di PT. 3A Precise Scale terdapat beberapa hasil MRP yang mempermudah perusahaan dalam kelancaran proses produksi seperti safety stock untuk timbangan digital Alexa yaitu 289 unit, DLE 329 unit dan untuk Precio yaitu 489 unit, sedangkan untuk hasil reorder point atau titik pemesanan kembali untuk timbangan digital Alexa yaitu 1617 unit, DLE 1843 unit dan untuk Precio yaitu 2735 unit.

Implementasi Odoo Manufacturing:

1. Membuat Database 
Langkah Pertama yang umum dilakukan waktu implementasi Odoo adalah membuat database baru untuk masing-masing perusahaan.

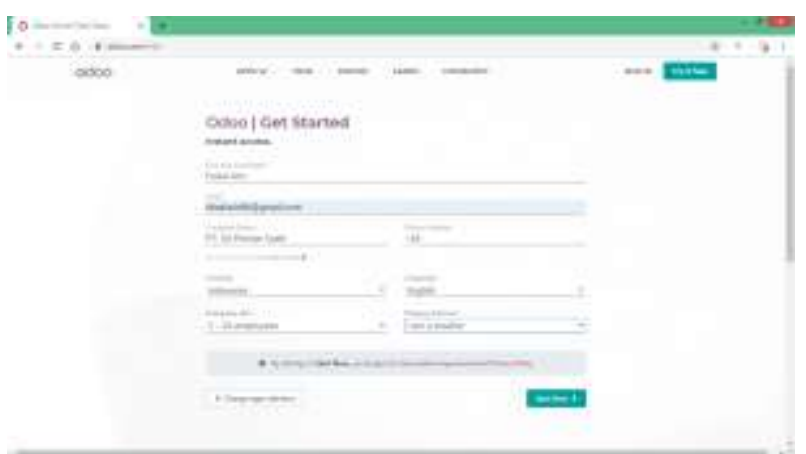

(Sumber: Software Odoo Manufacturing)

Gambar 4.9 Pembuatan Data Base

\section{Instal Modul MRP}

Step berikutnya kita perlu instal modul MRP untuk mempelajari akuntansi proses produksi. Yang dicakup pada modul MRP ini meliputi proses pembuatan barang jadi dari bahan baku, proses asembling atau perakitan barang jadi dari komponenkomponen, racikan barang jadi, paket produk yang terdiri dari beberapa produk lainnya, dan sebagainya.

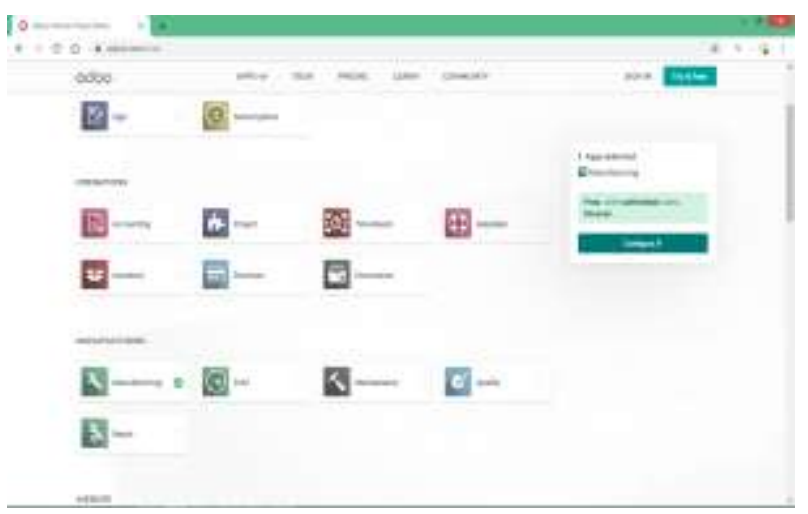

(Sumber: Software Odoo Manufacturing)

Gambar 4.10 Instal Modul Manufacturing

3. Definisi Produk Akhir

Langkah pertama adalah membuat produk yang merupakan gabungan dari produkproduk lainnya sebagai komponen.

Masuk ke menu:

\section{Inventory - Inventory Control - Product Klik Create.}

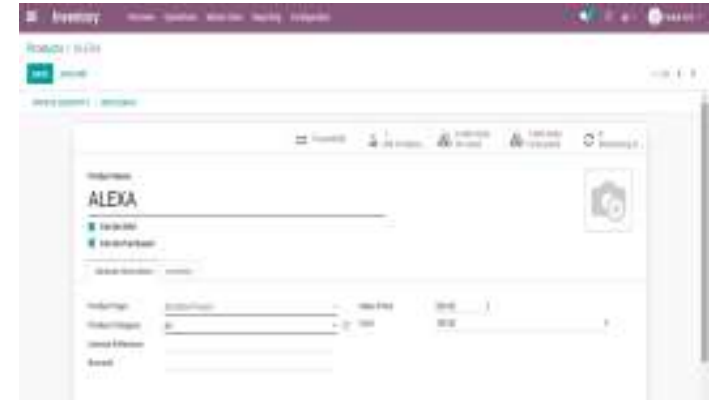

(Sumber: Software Odoo Manufacturing)

\section{DAFTAR PUSTAKA}

Alfatiyah, R. (2017). Perencanaan Produksi Minyak Telon Ukuran 100 Ml Dengan Metode Time Series Di Pt. Merpati Mahardika. Teknik Industri, 9(25).

Bastuti, S., Zulziar, M., \& Suaedih, E. (2020). Analisis Postur Kerja dengan Metode OWAS (Ovako Working Posture Analysis System) dan QEC (Quick Exposure Checklist) untuk Mengurangi Terjadinya Kelelahan Musculoskeletal Disorders di PT. Truva Pasifik. JITMI Jurnal Ilmiah Teknik dan Manajemen Industri, 2(2), 116-125.

Bastuti, S., Alfatiyah, R., Shobur, M., \& Candra, A. (2019). Manajemen Logistik.

Candra, A. (2019). Pengendalian Persediaan Material Pada Produksi Hot Mix Dengan Pendekatan Metode Economic Order Quantity (Eoq). Jitmi (Jurnal Ilmiah Teknik Dan Manajemen Industri), 1(2), 145-153.

Heizer, Jay, dan Barry Render. 2014. Manajemen Operasi. Edisi Kesebelas. Terjemahan oleh Kurnia Hirson, dkk. 2015. Jakarta: Salemba Empat.

Kurnia, D., Bastuti, S., \& Istiqomah, B. N. (2018). Analisis Pengendalian Bahan Baku Pada Produk Tas Dengan Menggunakan Metode Material Requirements Planning (Mrp) Untuk Meminimalkan Biaya Penyimpanan Di Home Industry Amel Collection. Jitmi (Jurnal Ilmiah Teknik Dan Manajemen Industri), 1(1), 22-28.

Murdifin Haming dan Mahfud Nurnajamudin. 2014. Manajemen Produksi Modern, Operasi Manufaktur dan Jasa. Buku Kesatu, PT. Bumi Aksara, Jakarta.

Russel, R.S dan Taylor, B.W. 2003. Operation Management. Prentice Hall. New Jersey. 